\title{
Ghouta Timur Pasca Pembebasan Bashar Al-Assad (Kajian Fenomenologi Edmund Husserl)
}

\author{
Fauziyah Kurniawati ${ }^{1}$ \\ ${ }^{1}$ Program Studi Bahasa dan Sastra Arab, Magister Universitas Islam Negeri Sunan Kalijaga, \\ Jl. Laksda Adisucipto Papringan, Caturtunggal, Kec. Depok, Kabupaten Sleman, Yogyakarta, 55281 \\ Penulis untuk Korespondensi/E-mail: 20201011024@student.uin-suka.ac.id
}

\begin{abstract}
This research article writing aims to describe East Ghouta post the deliverance of Bashar alAssad based on the perspective of phenomenology study of Edmund Husserl. The issues to be studied are: (1) how did the East Ghouta conflict start, Syria; and (2) how is Ghouta Timur after the release of Bashar al-Assad. The object under study is the national and international online news media. The research method used is the qualitative method. Data collection is used with watch and note techniques. The data analysis technique used is the descriptive analysis technique. To test the validity of data, the technique used is the triangulation technique. The results of this study are: (1) East Ghouta conflicts, Syria started on March 15, 2011. In addition to the background of the Arab Spring events, it turns out the level of emotionality of the President, Bashar al-Assad is quite lit whenever there is something that is not in his heart, which eventually led to hundreds of thousands of civilian lives lost and millions more fled; and (2) after 6 years of slipping into an inhumane empire, Ghouta was finally freed from the shackles of their warden by Bashar al-Assad.
\end{abstract}

Abstrak - Penulisan artikel penelitian ini bertujuan untuk mendeskripsikan Ghouta Timur pasca pembebasan Bashar al-Assad berdasarkan perspektif kajian fenomenologi Edmund Husserl. Adapun permasalahan yang akan diteliti, yaitu: (1) bagaimanakah awal mula konflik Ghouta Timur, Suriah; dan (2) bagaimanakah Ghouta Timur pasca pembebasan Bashar al-Assad. Objek yang dikaji adalah media berita online nasional dan internasional. Metode penelitian yang digunakan adalah metode kualitatif. Pengumpulan data digunakan dengan teknik tonton dan catat. Teknik analisis data yang digunakan adalah teknik analisis deskriptif. Untuk menguji keabsahan data, teknik yang digunakan adalah teknik triangulasi. Adapun hasil dari penelitian ini adalah (1) konflik Ghouta Timur, Suriah dimulai sejak tanggal 15 Maret 2011. Di samping dilatar belakangi oleh peristiwa Arab Spring, ternyata tingkat emosionalitas sang Presiden, Bashar al-Assad yang cukup menyulut-nyulut setiap kali ada suatu hal yang tidak berkenan di hatinya, yang pada akhirnya menyebabkan ratusan ribu jiwa masyarakat sipil harus hilang dan jutaan lainnya mengungsi; dan (2) setelah 6 tahun lamanya terpuruk dalam kungkung kekuasaan yang sama sekali tak berkeprimanusiaan, masyarakat Ghouta akhirnya dibebaskan dari belenggu sipir negeri mereka sendiri oleh Bashar al-Assad.

Keywords - East Ghouta, deliverance, Bashar al-Assad, phenomenology

\section{PENDAHULUAN}

$\mathrm{F}$ enomena adalah warna dalam mozaik kehidupan manusia. Bagaimana hidup akan terus berlanjut, bila fenomena manusia dan sekitarnya tiada. Bukan kehidupan namanya, bila tanpa disertai fenomena dalam setiap perputaran siang dan malam. Segala hal yang berkaitan dengan fenomena akan selalu asyik diperhatikan, diteliti, dan diperbincangkan, sehingga tak heran jika beberapa dari para ilmuwan berkenan dan berani mencetuskan sebuah teori yang kita kenal sebagai teori fenomenologi dalam mengkaji segala aspek kehidupan, sebut saja ekonomi, politik, budaya, agama, dan lain sebagainya. 
Sebut saja di Ghouta Timur, kota yang dewasa ini tengah ramai diperbincangkan penduduk dunia. Fenomena konflik dan serangan bersenjata dari rezim Suriah datang bertubi-tubi menghujam kota ini dan dengan sukarela menghilangkan nyawa anak-anak, wanita dan para orang tua, tanpa tahu dosa apa yang telah meraka perbuat. Baru-baru ini tersebar di media-media sosial dan berita internasional bahwa Bashar al-Assad telah membebaskan Ghouta Timur dari teror dan momentum luka yang cukup lama mendera seluruh masyarakat Ghouta Timur sejak tahun 2011 lalu.

Rezim Bashar al-Assad telah memblokade masyarakat Ghouta Timur selama lebih dari lima tahun terakhir ini. Saat itu pula Ghouta Timur, wilayah seluas 104 kilometer persegi yang mencakup beberapa distrik dan desa di bagian timur Damaskus sedang menghadapi salah satu gejolak krisis humanisme terbesar abad ke-21, yakni terjadinya perang saudara. Hal tersebut berdampak pada adanya kelaparan yang melanda bayi dan anak-anak Ghouta Timur.

Berdasarkan kacamata peneliti, hal ini akan sangat menarik jika diteliti atau dianalisis memakai teori fenomenologi Edmund Husserl melalui beritaberita terpercaya dan dapat dipertanggungjawabkan. Berdasarkan perkembangannya, teori fenomenologi disebut sebagai teori aliran filsafat yang sekaligus merupakan metode berpikir dalam mengkaji fenomena manusia (human phenomena) tanpa mengikutsertakan penyebab, realitas objektif, dan penampakan nyata dari fenomena itu sendiri.

Disebutkan bahwa fenomenologi tidak terlepas dari sebuah kebenaran perihal apa adanya sebuah fenomena itu tampak. Fenomenologi meyakini bahwa setiap fenomena yang tampak merupakan objek yang sarat akan makna supranatural. Sebab itulah, sebuah fenomena yang tampak itu semestinya dapat diterobos dan dilampaui untuk memperoleh sebuah hakikat kebenaran [1].

Pendiri sekaligus pencetus pertama kali aliran filsafat fenomenologi ini adalah Edmund Husserl. Ia mengutarakan bahwa fenomenologi merupakan suatu ilmu dasar dalam berfilsafat. Fenomenologi adalah ilmu perihal hakikat dan kebenaran serta memiliki sifat prioritas. Dengan demikian, makna fenomena menurut Edmund Husserl masih merupakan suatu pengembangan dari pemikiran Kant (noumena) [2].
Adapun yang dimaksud dengan penelitian fenomenologi adalah sebuah penelitian yang menginterpretasikan impresi dan sudut pandang masyarakat perihal suatu fenomena tertentu. Artinya, penelitian ini mencoba mengungkap bagaimana masyarakat menanggapi sebuah fenomena dengan berbagai asumsi yang ada. Dari sinilah, seorang peneliti dapat menggeneralisasikan sebuah pengalaman dan pemahaman ulung bersendikan perspektif dari orang-orang yang bersangkutan [3].

Berdasarkan pemaparan di atas, maka peneliti ingin mengungkap fenomena Ghouta Timur pasca pembebasan Bashar Assad dengan mengetahui awal mula konflik Ghouta Timur, Suriah dan Ghouta Timur pasca pembebasan Bashar al-Assad, tentunya dalam ranah kajian fenomenologi Edmund Husserl sesuai pemberitaan media nasional dan internasional.

\section{Hakikat Fenomenologi Edmund Husserl}

Secara etimologi, fenomenologi berasal dari bahasa Yunani "phainomai" yang memiliki arti "menampak". Artinya fenomena tiada bukan merupakan sebuah fakta yang diketahui, disadari dan masuk ke dalam pemahaman manusia. Jadi suatu objek fenomenologi memiliki pertalian dengan kesadaran. Dengan kata lain, fenomenologi mengelaborasikan pengalaman manusia secara langsung yang memiliki korelasi dengan suatu objek tertentu secara intensif [2].

Menurut The Oxford English Dictionary, yang dimaksud dengan fenomenologi adalah (a) the science of phenomena as distinct from being (ontology), dan (b) division of any science which describes and claasifies its phenomena. Artinya, fenomenologi adalah ilmu perihal fenomena, atau disiplin ilmu yang mendeskripsikan dan mengklasifikasikan bagaimana fenomena itu tampak serta bagaimana penampakannya [4].

Orlens menuturkan bahwa fenomenologi adalah suatu peranti untuk menafsirkan korelasi antara kesadaran individu dan kehidupan sosialnya secara mendalam. Fenomenologi berusaha mengekspresikan bagaimana manuver, kedudukan, dan entitas sosial masyarakat sebagai komoditas kesadaran manusia. Fenomenologi berasumsi bahwa masyarakat merupakan hasil eksposisi manusia [5].

Edmund Husserl menginterpretasikan fenomenologi sebagai teori yang mempelajari dan 
mengkaji kehidupan batiniyah individu, yakni fenomena-fenomena yang pernah dialaminya dalam garis batas kesadaran tiap individu tertentu [6]. Adapun intensi eminen dari fenomenologi adalah mengeksplorasi bagaimana fenomena dilakoni manusia dalam pikiran, tindakan, dan kesadarannya; seperti bagaimana fenomena tersebut memiliki nilai dan dapat disepakati dengan baik. Fenomenologi berupaya memecahkan sebuah resepsi tentang bagaimana manusia menafsirkan makna dan konsepsi prinsipil [4].

\section{Konsep Fenomenologi Edmund Husserl}

Penggagas sekaligus tokoh utama fenomenologi adalah Edmund Husserl. Ia menegaskan bahwa fenomena berdasarkan persepsinya berbeda dengan yang dideskripsikan oleh Immanuel Kant. Bila Immanuel Kant menuturkan bahwa suatu subjek hanya memahami fenomena dan bukan merupakan noumena, maka bagi Edmund Husserl, fenomena menyeluruhi noumena [4].

Menurut Husserl, suatu ilmu pengetahuan yang konklusif memerlukan pengawalan dari pendekatan filsafat fenomenologi. Berdasarkan pemahamannya, filsafat fenomenologi merupakan filsafat tanpa adanya ragam bias dan prasangka yang hanya dapat diketahui melalui metode reduksi. Metode ini mencoba memahami karakteristik fundamental kesadaran yang berupa intensionalitas. Ketika seseorang mulai menjabarkan dunia yang telah ia reduksi, maka ia akan segera menjumpai sebuah asumsi bahwa dunia tidaklah bersifat personal, akan tetapi dunia merupakan nilai dan makna yang disusun secara intersubjektivitas. Adapun intersubjektivitas bereksistensi dalam refleksi ego manusia secara natural dan terbentuk dari kausa internasionalitas [5].

Penafsiran Edmund Husserl ini bermula dari sebuah persuasi untuk kembali kepada realitas. Untuk itulah, metode reduksi yang sedikit disinggung di atas perlu dibentuk. Melalui metode reduksi, seseorang dapat mengarahkan ikhtisar sesuatu terhadap realitas. Beberapa langkah metodis yang dimaksud yaitu reduksi fenomenologi, reduksi eidetis, dan reduksi transendental [1].

Reduksi fenomenologi adalah langkah purifikasi fenomena yang mesti dilakukan oleh seorang peneliti. Dalam reduksi ini, semua bentuk aktivitas manusia yang dilakukan dalam ranah kesadaran perlu disortir sementara. Selama penelitian berlangsung pun, peneliti harus menelaah hal-hal di balik fenomena yang tampak dan menggali perihal dampak yang dialami suatu subjek di ranah kesadarannya. Dengan kata lain, melalui reduksi fenomenologi ini, peneliti berusaha menemukan hakikat dari suatu fenomena. Collins menyebut hal tersebut sebagai langkah "bracketing" untuk mengungkap kemurnian fenomena. Sebab itulah, ketika seorang peneliti memutuskan untuk memulai aksinya, maka ia harus menanggalkan semua simbol miliknya, seperti agama, pangkat, adat istiadat, dan perspektifnya perihal ilmu pengetahuan [5].

Selain itu, tendensi fungsi dari reduksi fenomenologi adalah menjabarkan kaidah sebuah objek yang tampak dalam susunan bahasa yang baik. Hal itu tidak hanya dalam terminologi objek secara eksternal, melainkan juga kesadaran dalam perilaku internal, pengalaman, dan korelasi antara fenomena dengan subjek yang mengkajinya. Titik pusatnya didasarkan pada kadar pengalaman, sedangkan poros sensasinya dilandaskan pada pemenuhan sifat-sifat alamiah dan substansi dari pengalaman itu sendiri [4].

Tahapan reduksi yang kedua dalam penelitian dengan perspektif fenomenologi adalah reduksi eidetis. Reduksi ini bermaksud untuk mendapatkan intipati dari sebuah hakikat [5]. Reduksi ini bertujuan untuk menemukan struktur dasar dalam mencapai hal-hal yang hakiki. Segala dimensi aksidensial yang berupa ruang, waktu, dan sejenisnya, masih dikategorikan pada proses filtrasi (bracketing method) [4].

Selanjutnya tahap reduksi ketiga dalam penelitian dengan teori fenomenologi adalah reduksi transendental. Reduksi transendental berupaya mengklasifikasi hakikat yang bersifat empiris untuk kemudian menjadikannya sebagai hakikat murni. Setelah disortir, suatu aktivitas empiris akan membentuk aktivitas di atas kesadaran murni agar kemudian dapat memformulasikan suatu objek tertentu. Pada fase inilah subjek menjadi dirinya sendiri dan menggapai kebenaran yang memiliki kesesuaian antara apa-apa yang dilihat, dipikir, dan dialami dengan substansi makna yang tercipta [5].

Edmund Husserl mendeteksi sebuah eksistensi hakikat kesadaran atau intensionalitas melalui proses reduksi transendental. Definisi kesadaran selalu dikaitkan dengan objek dari kesadaran itu sendiri. Hal yang paling esensial dalam reduksi transendental bukanlah terletak pada persoalan filtrasi fenomena yang tampak, akan tetapi pada 
metode pemberian interpretasi subjek terhadap objek yang dikajinya [2].

Berdasarkan peninjauannya terhadap struktur intensionalitas kesadaran, Edmund Husserl memformulasikan empat aktivitas yang esensial dalam kesadaran, yaitu: rasionalisasi, rekognisi, interelasi, dan preskripsi [4].

\section{Penggunaan Teori dalam Fenomenologi Edmund Husserl}

Pada hakikatnya, penelitian fenomenologi memiliki prinsip a priori, artinya teori ini tidak dilandasi oleh teori yang lain. Teori fenomenologi ini justru lahir dari perspektif filsafat perihal apa yang dikaji dan bagaimana cara mengkajinya. Berikut ini merupakan tiga asumsi konsep dasar penelitian fenomenologi, yaitu [4]:

a. Sebuah peristiwa memiliki arti dan makna tersendiri bagi orang-orang yang mengalaminya secara langsung.

b. Penafsiran objektif diproses mengikutsertakan pengalaman subjektif.

c. Pengalaman manusia tidak dikonstruksi oleh peneliti.

\section{Bashar Al-Assad}

Bashar al-Assad merupakan Presiden Suriah setelah Hafeez Assad. Ia memimpin Suriah selama kurang lebih 20 tahun, sejak tahun 2000 hingga saat ini. Konsistensi Bashar al-Assad memimpin Suriah selama itu tidak terlepas dari desas-desus keberhasilannya mengangkat Human Development Index (HDI) di Suriah yang berada para urutan 111 versi PBB. Human Development Index adalah evaluasi atas keberhasilan pembangunan di sebuah negara yang berlandaskan pada sejumlah variabel, seperti angka harapan hidup, pendapatan penduduk, tingkat pendidikan, dan angka melek huruf [7].

Bashar al-Assad menggantikan posisi ayahnya sebagai presiden dan menjalin hubungan baik dengan Rusia, Iran, Korea Utara, Cina, dan beberapa negara di Amerika Latin yang membantah paham imperialisme Amerika Serikat beserta sekutunya. Ia melanjutkan kepemimpinan dan kiprah politik mendiang ayahnya dengan meneruskan perjuangan ayahnya dalam ranah pemerintahan Suriah [8].

Selama masa kepemimpinannya, Bashar al-Assad banyak menjalankan kebijakan, di antaranya adalah mengupayakan alasan proses damai negara Arab dengan Israel, kehadiran militer Suriah di Lebanon, dan hubungan Suriah dengan dunia dalam ranah kebijakan luar negeri. Menjelang berlangsungnya kepemimpinan Bashar al-Assad, sampailah isu bahwa akan ada perbaikan pada sistem politik pemerintahan dan perekonomian. Ia mengerahkan dukungan penuh dalam kedua bidang tersebut dan memperketat sistem kekuasaannya. Kepemimpinan Bashar al-Assad menjadi harapan baru bagi rakyat Suriah [8]. Dalam hal ini tentu diharapkan pula agar segala konflik yang terjadi di Suriah dapat diakhiri dengan damai.

Penelitian kajian fenomenologi Edmund Husserl telah banyak dilakukan oleh kalangan akademisi. Diantaranya adalah Marthalena (2017) dan Solihah (2018). Marthalena (2017) mengkaji studi dampak implementasi motto kota Serang. Hasil penelitian ini menunjukkan bahwa dengan melihat berbagai fenomena yang muncul di lapangan, maka dapat disimpulkan bahwasanya motto kota Serang Madani tidak dilaksanakan di tengah-tengah kehidupan kota Serang karena rendahnya kesadaran diri (self consiusnes) kota Serang untuk mematuhi peraturan yang ditetapkan oleh pemerintah kota Serang [9]. Sedangkan Solihah (2018) mengkaji nilai-nilai kehidupan dari kisah Nabi Syu'aib a.s. dalam al-Qu'an. Hasil penelitian ini menunjukkan bahwa: a) reduksi fenomenologinya yaitu Nabi Syu'aib diutus kepada negeri Madyan yang berperilaku tidak mau memenuhi dan mengikuti ajakannya untuk menyembah Allah; b) reduksi eidetisnya yaitu sebagai ibrah yang memberikan pelajaran tentang perilaku manusia yang dihilangkan peradabannya disebabkan perilaku mereka yang sudah jauh dari syariat agama; dan c) reduksi transedentalnya adalah redaksi kenabian Nabi Syu'aib a.s. [10].

Penelitian yang memiliki fokus membahas konflik di Ghouta Timur pernah dilakukan, yaitu oleh Sakti dan Rahayu (2019). Penelitian ini membahas pandangan hukum humaniter internasional terhadap kecamuk senjata pemerintah Suriah di Ghouta Timur pada bulan Februari 2018. Hasil penelitian menunjukkan bahwa Suriah merupakan negara yang hanya melakukan pengesahan terhadap beberapa peraturan mengenai hukum humaniter internasional, di antaramya yaitu: Konvensi Jenewa Tahun 1949, Protokol Tambahan I Tahun 1977, dan Konvensi Senjata Kimia Tahun 1993 [11].

Penelitian tersebut lebih berfokus kepada bagaimana sistem hukum humaniter internasional bekerja ketika dihadapkan pada satu kondisi di mana telah terjadi kecamuk senjata dari pemerintah 
Suriah terhadap Ghouta Timur pada bulan Februari 2018. Adapun dalam penelitian ini akan berfokus pada fenomena awal mula adanya konflik di Ghouta Timur dan bagaimana kondisi Ghouta Timur pasca pembebasan Bashar al-Assad dengan menggunakan pendekatan teori fenomenologi dari Edmund Husserl.

\section{METODE}

Penelitian ini merupakan penelitian deskriptif kualitatif dengan sumber data penelitian yang diambil dari beberapa berita faktual mengenai konflik di Ghouta Timur yang peneliti dapatkan melalui website internet. Adapun tahap penelitiannya adalah sebagai berikut:

1. Menelaah berita-berita terpercaya terkait konflik di Ghouta Timur dengan saksama demi menemukan data yang berhubungan dengan kajian fenomenologi dari Edmund Husserl.

2. Memilih data yang terkait dengan kajian fenomenologi dari Edmund Husserl dan membatasi data yang tidak terkait.

3. Mengategorikan data yang memiliki keterkaitan dengan kajian fenomenologi dari Edmund Husserl.

4. Menganalisis dengan melakukan pembacaan intensif terhadap berita-berita terkait konflik di Ghouta Timur dan menelaahnya dengan teliti.

5. Menarik kesimpulan.

\section{HASIL DAN PEMBAHASAN}

\section{Awal Mula Konflik Ghouta Timur}

Setiap peristiwa memiliki awal dan permulaannya, begitu pula dengan konflik yang terjadi di Ghouta Timur, Suriah. Pada artikel penelitian ini, peneliti memfokuskan analisis berita perihal reduksi fenomena awal mula konflik Ghouta Timur, begitu pula nanti pada pembahasan kedua mengenai Ghouta Timur pasca pembebasan Bashar Assad. Adapun sumber pembahasan artikel ini peneliti kumpulkan dari berbagai sumber berita tanah air dan mancanegara. Berita pertama peneliti dapatkan dari sebuah video berita TRT WORLD di sebuah akun instagram [12] yang pada awal video disebutkan:

\footnotetext{
"Ini adalah cerita bagaimana tulisan grafiti memicu terjadinya revolusi. Di suatu sore, seorang remaja laki-laki memagang cat semprot hitam. Dia berkata bahwa remaja lain yang lebih tua darinya menyuruhnya
}

untuk membuat tulisan di dinding sekolahnya, (جأك الدور يادكتور). , yang artinya "Sekarang giliranmu, wahai Doktor (Bashar Assad). Kalimat inilah yang memicu terjadinya perang di Suriah."

Video berita ini dengan sangat detail menyebutkan bahwa awal pemicu perang dan segala keresahan di Ghouta, Suriah adalah karena ketidaksenangan Presiden Bashar al-Assad terhadap ulah remaja tersebut, yang mana hal ini juga bersamaan dengan adanya Arab Spring. Hari itu, tanggal 06 Maret 2011 ada sekitar 15 remaja ditangkap oleh tentara partai Assad. Orang tua mereka panik dan meminta agar anak-anaknya segera dibebaskan. Namun para tentara justru membuat statement baru yang membuncahkan amarah masyarakat Suriah waktu itu perihal anak-anak yang tidak akan dibebaskan. Setelah hari itu, kerincuhan mulai melanda Daraa, banyak korban jatuh lantaran membangkang kepada petugas pemerintahan.

Seminggu kemudian, berbagai aksi protes, pemberontakan dan pembunuhan semakin merajalela di negeri ini. Tepat hari itu pula 15 anak remaja dibebaskan oleh Assad, namun perlawanan terhadapnya tak kunjung reda. Mereka mengiginkan Assad diturunkan dari jabatannya sebagai presiden Suriah. Karena persoalan itulah, pasukan tentara di Suriah terpecah menjadi dua, pasukan tentara sipil dan pasukan tentara yang masih setia pada Assad. Dan mulai tahun 2011, tercatat ada 500.000 orang tewas dan 10 juta orang mengungsi ke tempat lain demi keamanan mereka. Saat ini, konflik melibatkan orang-orang di belahan dunia yang datang mendukung kelompok yang berbeda-beda di Suriah ini. Jadi pada hari itu, 15 Maret 2011, revolusi di Suriah mulai dicanangkan, namun harus berakhir menjadi konflik berkelanjutan yang menewaskan ratusan ribu rakyat sipil dan membuat jutaan lainnya mengungsi di daerah-daerah perbatasan.

Berita selanjutnya dari ISLAMPOS Maret 2018, yang diawali dengan kalimat pernyataan sebagai berikut [12]:
"Pada bulan Maret 2018 ini, konflik Suriah akan memasuki tahun ke-8. Sudah lebih dari 465 ribu warga Suriah tewas dalam arena konflik, lebih dari satu juta orang terluka, dan lebih dari 12 juta warga telah mengungsi dan terusir dari rumah mereka. Apa yang menyebabkan terjadinya konflik tersebut?" 
Berita ini melengkapi data berita pertama yang peneliti analisis. Peristiwa Arab Spring pada tahun 2011 dianggap menjadi titik keberhasilan misi pemberontakan sekaligus menyulut pretensi untuk mengudeta presiden Tunisia dan Mesir. Hal ini kemudian menjadi harapan bagi aktivis prodemokrasi Suriah. Pada bulan Maret saat itu, demonstrasi damai meledak di Suriah, hingga menyebabkan beberapa demonstran ditahan dan digeledah aparat. Tahun demi tahun, berbagai macam konflik dan pemberontakan seakan memborbardir kawasan Suriah dari pihak Amerika Serikat dan Rusia. Setelah Aleppo menjadi salah satu sasaran kecamuk senjata, pemberontakan di Suriah berlanjut di dua front wilayah utama, yakni Ghouta Timur dan Afrin. Pasukan pemerintah Suriah yang mendapat dukungan dari pesawat tempur Rusia tidak berhenti menyerang wilayah Ghouta Timur dan mengakibatkan ratusan warga sipil tewas.

Selanjutnya pada awal bulan Januari 2018, Afrin, Turki dan Free Syria Army (FSA) mulai mencanangkan operasi militer melawan YPG di wilayah barat laut Suriah. Ghouta Timur mulai dikepung sejak tahun 2013. Sampai detik ini pun, konflik Suriah yang berpusat di Ghouta Timur masih saja memanas, hingga menjatuhkan ribuan warga sipil sebagai korbannya. Sengketa antara pemerintah dan para pemberontak telah menjelma menjadi genosida massal yang menyebabkan Ghouta dan Afrin seumpama neraka bagi rakyatnya sendiri.

Kemudian berita selanjutnya bersumber dari QnA Kumparan News dengan kalimat utama di bawah ini [13]:

\section{"Mengapa Rezim Suriah menyerang Ghouta?"}

Berita tersebut memaparkan alasan rezim Bashar Assad menyerang Ghouta dengan teramat jelas. Ghouta merupakan wilayah krusial bagi Bashar Assad. Posisnya hanya selemparan batu daripada ibu kota Damaskus, kurang leboh 30 sampai 40 kilometer. Sebelum adanya konflik merongrong wilayah ini, Ghouta dikenal sebagai lahan perkebunan sekaligus lumbung padi bagi Damaskus. Dari wilayah ini pula, pejuang oposisi bebas menembakkan rudal ke pusat kota Damaskus. Ghouta Timur adalah enklave terakhir yang masih dianeksasi oleh para pemberontak rezim Bashar Assad.
Sejak tahun 2013, berbagai bentuk agresi terhadap Ghouta Timur telah mulai dilancarkan oleh para tentara Suriah. Salah satunya adalah kecamuk senjata kimia yang berhasil menewaskan 1.500 penduduk Ghouta. Ada beberapa kelompok oposisi yang berebut mengambil alih kekuasaan di daerah Ghouta Timur, yaitu: 1) militan tentara Islam menguasai daerah utara, Douma, dan bagian timur enklave; 2) kelompok Failaq al-Rahman menguasai daerah barat daya enklave; dan 3) Arhar al-Sham menguasai daerah barat laut enklave. Motif perebutan wilayah ini menjadi bumerang bagi masyarakat Ghouta Timur yang pada akhirnya berujung pada luka dan kematian.

Dari ketiga pemberitaan di atas, peneliti rasa sudah cukup memadai untuk mengetahui dan memahami awal mula penyebab konflik berkepanjangan di Ghouta Timur, Suriah. Reduksi fenomenologi yang ditemukan di sini adalah konflik Ghouta Timur dilatar belakangi oleh peristiwa Arab Spring. Reduksi eidetisnya adalah ketidaktegasan pemerintah Suriah melerai setiap konflik yang dating. Dan reduksi transedentalnya ada pada tingkat emosionalitas sang Presiden, Bashar alAssad yang cukup menyulut-nyulut setiap kali ada suatu hal yang tidak berkenan di hatinya, yang pada akhirnya berujung pada suatu keputusan yang seharusnya tidak layak diputuskan oleh seorang pemimpin sebuah negara.

\section{Ghouta Timur Pasca Pembebasan Bashar Assad}

Seperti halnya awal, setiap peristiwa dan fenomena pun juga memiliki akhir. Setelah 6 tahun lamanya terpuruk dalam kungkung kekuasaan yang sama sekali tak berkeprimanusiaan, masyarakat Ghouta akhirnya dibebaskan dari belenggu sipir negeri mereka sendiri. Akhirnya sang Presiden, Bashar alAssad terketuk sedikit celah dari pintu hatinya untuk sekadar membebaskan masyarakat Ghouta bernafas seperti seharusnya.

Setelah menelaah beberapa sumber media dan berita terkait, inilah salah satu berita yang peneliti kaji menggunakan teori fenomenologi Edmund Husserl perihal Ghouta Timur pasca pembebasan Bashar al-Assad. Menilik pada berita pembebasan Ghouta oleh Bashar Assad di salah satu akun sosial peneliti muda Timur Tengah, Dina Y. Sulaeman, berikut pernyataannya [14]:

\footnotetext{
"Jauh bersinggungan dengan kalimat para pengumpul donasi "Save Ghouta", pada kenyataannya justru saat ini Ghouta telah bebas, Ghouta is saved."
} 
Dina Y. Sulaeman menuliskan dalam salah satu artikelnya bahwa kini masyarakat Ghouta Timur telah dibebaskan. Pada penyelidikan dan proses evakuasi Ghouta Timur, tentara Suriah menemukan reserve senjata berbahan kimia yang berasal dari Saudi dan baju pelindung zirah dari negara Barat. Hal seperti ini juga pernah terjadi pada konflik Aleppo sebelum ini. Untuk menghilangkan segala jejak peperangan yang pernah terjadi, tentara Suriah melakukan perjanjian dengan para wajib militer teror Ghouta. Isi perjanjian tersebut adalah:

- wajib militer akan dipindah tugaskan ke Idlib.

- semua tawanan yang ditaksir berjumlah ribuan akan dibebaskan dari penjara-penjara al-Nushra dan Failaq al-Rahman.

- para wajib militer menyerahkan peta terowongan dan data ranjau yang mereka tanam kepada tentara Suriah.

- memindah tangankan senjata berat dan menengah ke pemerintah.

Pada akhir pembahasan, Dina Y. Sulaeman menunjukkan hasil terjemahannya tentang status Hadi Nasrullah yang aktif menulis perihal perkembangan kondisi di Suriah tetanggal 23 Maret 2018. Begini isinya [14]:

Ghota Timur secara resmi dibebaskan dari Al Qaeda atau "pemberontak moderat", kata media politik Barat. Tidak, terimakasih telah ditujukan kepada Amerika Serikat, Inggris, Uni Eropa, Saudi, Qatar, dan Turki, melainkan kepada Syrian Arab Army (SAA). Warga Damaskus akhirnya akan beristirahat tenang berkat SAA dan sekutunya yang setia. Tidak ada lagi "jihadis" yang akan menembakkan serangan mortir dan membantai warga kota. Tidak ada lagi rasa takut bahwa rudak tibatiba saja jatuh meledakkan sekolah, pasar, jalanan, dan rumah sakit. Enam tahun berlalu, kini orang-orang Damaskus akan tidur dengan damai dan menjalani kehidupan sehari-hari mereka tanpa khawatir akan serangan mematikan yang mendadak datang.

Tembakan mortir yang berasal dari Ghouta Timur yang dilakukan "pemberontak moderat" telah menargetkan warga sipil di Damaskus dan menewaskan lebih dari 900 orang (sebagian besar wanita dan anakanak) pada tahun 2016 saja, belum terhitung jumlah korban di tahun-tahun lainnya. Inilah kemenangan Suriah melawan terorisme global yang mendapat dukungan dari Barat, Turki, Israel, dan GCC (negara Teluk). Sekarang media dan para humanis akan melupakan Ghouta Timur seperti yang mereka lakukan terhadap Aleppo. Tahun 2016 lalu, mereka berteriak histeris "Save Aleppo", hingga sampai saat pemerintah berhasil mengusir teroris dari wilayah Aleppo dan menciptakan suka cita bagi rakyat Aleppo.

Beberapa wilayah Suriah masih berada di bawah pendudukan Israel, Al Qaeda dan afiliasinya, Turki, serta Kurdi yang didukung oleh Amerika Serikat. Perang tidak akan berhenti sampai SAA memberi kebebasan kepada setiap inci wilayah Suriah untuk memulihkan kembali keamanan bagi seluruh warga Suriah dengan latar belakang etnis dan agama yang berbeda sepenuhnya.

Dari data di atas ditemukan hasil bahwa reduksi fenomenologi atas fenomena Ghouta Timur pasca pembebasan Bashar al-Assad adalah ditemukannya bukti campur tangan Al-Qaeda atau pemberontak moderat dalam konflik yang mendera dan meresahkan warga Ghouta. Kemudian reduksi eidetisnya adalah orang-orang Ghouta dan Damaskus terbebas dari jerat kegelisahan dan penderitaan yang mereka alami selama masa pemberontakan berlangsung dengan sangat tidak berprikemanusiaan. Terakhir, reduksi transedental dari fenomena ini adalah upaya pembebasan kamp Douma, Yarmouk dan Hajar al-Aswad di Damaskus dari ISIS dan afiliasi Al Qaeda. Tersebab pada hakikatnya, perang dan kerincuhan tidak akan berhenti sampai pada saatnya Syrian Arab Army membebaskan setiap inci wilayah Suriah untuk memulihkan kembali keamanan secara penuh bagi seluruh warga Suriah dengan distingsi latar belakang etnis dan agama.

Dari sini, kiranya cukup jelas mengenai Ghouta Timur pasca pembebasan Bashar al-Assad. Ada senyum tulus yang merekah dari bibir masingmasing warga Ghouta, memuja kekuasaan-Nya dalam setiap inci kehidupan. Ghouta is Saved.

\section{KESIMPULAN}

Berdasarkan elaborasi terhadap pembahasan di atas, maka kesimpulan dari penelitian ini adalah sebagai berikut: 
1. Konflik Ghouta Timur, Suriah dimulai sejak tanggal 15 Maret 2011. Di samping dilatar belakangi oleh peristiwa Arab Spring, ternyata tingkat emosionalitas sang Presiden, Bashar alAssad yang cukup menyulut-nyulut setiap kali ada suatu hal yang tidak berkenan di hatinya, yang pada akhirnya berujung pada suatu keputusan yang seharusnya tak layak diputuskan oleh seorang pemimpin sebuah negara. Karena itulah, ratusan ribu jiwa masyarakat sipil harus hilang dan jutaan lainnya mengungsi.

2. Setelah enam tahun lamanya terpuruk dalam kungkung kekuasaan yang sama sekali tak berkeprimanusiaan, masyarakat Ghouta akhirnya dibebaskan dari belenggu sipir negeri mereka sendiri. Akhirnya sang Presiden, Bashar al-Assad terketuk sedikit celah dari pintu hatinya untuk sekadar membebaskan masyarakat Ghouta bernafas seperti seharusnya.

\section{REFERENSI}

[1] Basrowi dan Sukidin, Metode Penelitian Kualitatif Mikro, Surabaya: Cendekia, 2002.

[2] M. Munir, Aliran-aliran Utama Filsafat Barat Kontemporer, Yogyakarta: Lima, 2018.

[3] A. Sobur, Filsafat Komunikasi Tradisi dan Komunikasi Fenomenologi Konsepsi, Pedoman, dan Contoh Penelitiannya, Semarang: Widya Padjajaran, 2009.

[4] E. Kuswarno, Metodologi Penelitian Komunikasi Fenomenologi Konsepsi, Pedoman, dan Contoh Penelitiannya, Semarang: Widya Padjajaran, 2009.

[5] I. B. Wirawan, Teori-teori Sosial dalam Tiga Paradigma (Fakta Sosial, Definisi Sosial \& Perilaku Sosial), Jakarta: Kencana, 2012.

[6] W. Bachtiar, Metode Penelitian Kualitatif Mikro, Surabaya: Insan Cendekia, 2002.
[7] D. Y. Sulaeman, Prahara Suriah: Membongkar Persekongkolan Multinasional, Depok: Pustaka Ilman, 2013.

[8] M. Muhammad, "Kebijakan Politik Pemerintahan Bashar Al-Assad di Suriah", IN RIGHT: Jurnal Agama dan Hak Azazi Manusia, vol. VI, no. 1, pp. 84-88, November 2016.

[9] Marthalena, "Studi Dampak Implementasi Motto Kota Serang dengan Pendekatan Teori Fenomenologi Husserl", SAWALA, vol. V, no. 1, pp. 31-36, April 2017.

[10] Solihah, "Nilai-nilai Kisah Nabi Syu'aib a.s. dalam Al-Qur'an dengan Pendekatan Fenomenologi Edmund Husserl", Skripsi Fakultas Ushuluddin UIN Sunan Gunung Djati Bandung, 2018.

[11] G.Sakti dan S. L. Rahayu, "Tinjauan Hukum Humaniier Internasional terhadap Serangan Pemerintah Suriah di Ghouta Timur pada Februari 2018", Belli Ac Pacis, vol. V, no. 2, pp. 53-62, Desember 2019.

[12] E. Susanti, "Begini Kronologi Konflik Suriah, termasuk Ghouta Timur dan Afrin", Islam Pos, 2018. [Online]. Available: https://www.islampos.com/74001-74001/. [Diakses 16 Januari 2021].

[13] D. Armandhanu dan N. Hidayati, "QnA: Mengapa Rezim Suriah Menyerang Ghouta?", Kumparan News, 26 Februari 2018. [Online]. Available:

https://kumparan.com/@ kumparannews/qnamengapa-rezim-suriah-menyerang-ghouta.

[Diakses 16 Januari 2021].

[14] D. Y. Sulaeman, "Ghouta is Saved," Dina Sulaeman WordPress, 24 Maret 2018. [Online]. Available: https://dinasulaeman.wordpress.com/2018/03/ 24/ghouta-is-saved/. [Diakses 16 Januari 2021]. 